\title{
Article \\ Exploring the Influence Mechanism of Farmers' Organic Fertilizer Application Behaviors Based on the Normative Activation Theory
}

\author{
Jinhua Xie ${ }^{1,2}$, Gangqiao Yang ${ }^{1, *}$, Zhaoxia Guo ${ }^{1}$ and Ge Wang ${ }^{1,3}(\mathbb{D}$ \\ 1 College of Public Administration, Huazhong Agricultural University, 1 Shizishan Street, \\ Wuhan 430070, China; xiejinhua01@webmail.hzau.edu.cn (J.X.); guozx@mail.hzau.edu.cn (Z.G.); \\ ge.wang@mail.hzau.edu.cn (G.W.) \\ 2 Department of City and Regional Planning, The University of North Carolina at Chapel Hill, \\ Chapel Hill, NC 27599, USA \\ 3 Antai College of Economics and Management, Shanghai Jiao Tong University, 1954 Huashan Road, \\ Shanghai 200030, China \\ * Correspondence: ygq@mail.hzau.edu.cn; Tel.: +86-139-7166-9174
}

check for updates

Citation: Xie, J.; Yang, G.; Guo, Z.; Wang, G. Exploring the Influence Mechanism of Farmers' Organic Fertilizer Application Behaviors Based on the Normative Activation Theory. Land 2021, 10, 1111. https:// doi.org/10.3390/land10111111

Academic Editors: Rachid Mrabet, Haddioui Abdelmajid,

Hamdali Hanane and Abbas Younes

Received: 10 September 2021

Accepted: 18 October 2021

Published: 20 October 2021

Publisher's Note: MDPI stays neutral with regard to jurisdictional claims in published maps and institutional affiliations.

Copyright: (c) 2021 by the authors. Licensee MDPI, Basel, Switzerland. This article is an open access article distributed under the terms and conditions of the Creative Commons Attribution (CC BY) license (https:// creativecommons.org/licenses/by/ $4.0 /)$.

\begin{abstract}
This paper establishes an analysis framework to investigate the effect of the awareness of consequences and the ascription of responsibility on farmers' organic fertilizer application behaviors (OFABs). Using questionnaire survey data from Hubei Province, one of the main grain-producing areas in China, this study employed both mediating effects and moderating effect analytical methods to analyze the influencing mechanism of the awareness of consequences and ascription of responsibility on farmers' OFABs. The results show that, firstly, the awareness of consequences and ascription of responsibility have a significant positive impact on farmers' OFABs. The improvement in farmers' awareness of consequences and ascription of responsibility can effectively promote the utilization of organic fertilizers for enhanced ecological production. Secondly, the awareness of consequences and ascription of responsibility have a significant positive impact on farmers' OFABs through individual farmers' personal norms. Increasing farmers' awareness of consequences and ascription of responsibility firstly stimulates their personal norms; then, personal norms have a positive impact on farmers' OFABs. Thirdly, farmers' social norms can positively regulate the relationship between personal norms and their OFABs. The higher the social norms of farmers, the more their social norms can have a positive regulating effect on their OFABs. Therefore, in the future, it will be necessary to vigorously promote farmers' awareness of consequences and ascription of responsibility, in order to enhance farmers' social norms, and to improve the level of farmers' social norms, in order to greatly promote farmers' engagement in OFABs. This will ultimately better promote rural ecological environmental protection and ecological civilization construction.
\end{abstract}

Keywords: awareness of consequences; ascription of responsibility; organic fertilizer application behaviors (OFABs); normative activation theory

\section{Introduction}

With the rapid socio-economic growth and the increase in the population of China, to guarantee food safety for nearly $20 \%$ of the global population, China utilizes the world's largest amount of chemical fertilizers (almost 30\% of the global total) [1]. Increasing the use of chemical fertilizers is beneficial to food production, but their use also leads to soil degradation, agricultural carbon emissions, and water pollution [2-6]. Studies have shown that crops absorb just 30 to $50 \%$ of chemical fertilizers, and a large number of chemical fertilizers permeate the soil and contaminate the underground water [7]. Due to the saturation of chemical fertilizers in the soil, the utilization efficiency is declining $[7,8]$. Some researchers allege that this represents an overuse of chemical fertilizers [9] and lead to a 
decline in the soil quality of cultivated land [10]. Creating an environmentally friendly agricultural production system and guiding farmers to adopt environmentally friendly production behaviors are critical means to prompt the transformation of production modes. Specifically, a transformation from boosting production to promoting value and achieving the sustainable development of agriculture should be established [11]. Meanwhile, the promotion and use of organic fertilizer are key solutions to the establishment of an environmentally friendly agricultural production system in China. Organic fertilizers are a type of fertilizer with special-function microorganisms and organic matter that is mainly composed of pre-treated animal and plant residues (e.g., livestock waste, crop straw), which are produced through a harmless treatment process [12]. They contain trace amounts of nitrogen and other minerals that promote healthy crop growth during the season of application, with the primary benefit of maintaining the soil structure [13], which can improve long-lasting soil fertility [14]. Thus, the application of organic fertilizer can increase the organic matter in the soil and improve the activity of its enzymes and microorganisms [15]. Therefore, we aim to guide farmers to use organic fertilizers during agricultural production in Hubei Province, which is one of the main grain-producing areas in China.

Recently, academia has conducted numerous discussions on farmers' organic fertilizer application behaviors (OFABs). Some scholars have mainly studied the topic from the perspectives of social capital [16,17], land property rights stability [18,19], farm size [11,20], non-agricultural employment [21], knowledge training [22,23], risk attitudes [24-26], government subsidies [20], agricultural insurance and loans [27], land reallocation [28], extension services [20], and fertilizer supply chains [29]. By combing through the existing literature, this paper found that the existing research perspectives still need to be expanded in the following aspects: First, although existing studies analyze farmers' OFABs from different perspectives, they rarely analyze them from the perspective of social psychology theory. The research results regarding OFABs are not perfect; they fail to fully reveal the mechanism of action of farmers' decision-making as related to OFABs. Second, the existing literature seldom analyzes the influence of the awareness of consequences and ascription of responsibility on farmers' OFABs, based on the perspective of norm activation theory. The awareness of consequences and ascription of responsibility can affect farmers' OFABs by activating their personal norms. Third, the existing literature does not fully consider the moderating effect of social norms. In the external context of social norms, how the internal mechanism of farmers' awareness of consequences and ascription of responsibility affects their OFABs through personal norms is still unclear. Therefore, this paper used questionnaire survey data of 391 farmers in Wuhan city, Jingmen city, Huangshi city, and Tianmen city, all of which are in Hubei Province, to construct an analytical framework regarding the influence mechanism of farmers' OFABs based on the normative activation theory. A structural equation model was used to explore the influencing mechanism and to try to formulate reasonable promotion policies that the government can implement to guide farmers to use organic fertilizers. This will provide scientific support and reference for the decision-making of those responsible for ecological civilization construction. Thus, this study formulated the following two research questions (RQs).

- RQ1: What is the influencing mechanism of the awareness of consequences and ascription of responsibility on farmers' OFABs?

- RQ2: Can social norms moderate the relationship between personal norms and farmers' OFABs?

The results of this research could inform strategies to reduce environmental damage through interventions (e.g., fostering environmental attitudes and emotions) to influence individual participation in IRHS.

The rest of this paper is organized as follows: The second part contains the theoretical analysis and research hypothesis. The third part introduces the data sources, variable settings, and research methods. The fourth part introduces the results of this empirical study, including the model fitting test, intermediary effect analysis, and moderating effect 
analysis. The findings and limitations to be further studied are discussed in Section 5. Finally, the conclusions and policy implications are presented in Section 6.

\section{Theoretical Analysis}

The normative activation theory (NAT), originally developed by Schwartz [30], is a mature theory used to explain pro-social behaviors. The NAT is also aimed at investigating individual pro-environmental behavior/intentions [31,32]. As one critical aspect of pro-social behavior, pro-environmental behaviors have also attracted significant attention [33,34]. Additionally, many scholars have discussed OFABs. Farmers' OFABs are beneficial to environmental protection; they also promote the sustainable development of agriculture. Taking into account the contextual role of social norms, the NAT has been expanded by incorporating "social norms". This paper used the extended model of the NAT to investigate the pro-environmental behavior of farmers. This is helpful to improve the predictive and explanatory power of environmental behavior [35]. Therefore, based on the fundamental model of the NAT, this study constructed an analytical framework that illustrates the influence mechanism of farmers' OFABs (Figure 1). According to the existing results [30,34], the NAT mainly incorporates three types of variables to predict farmers' OFABs. The first is personal norms (PNs). Typically, a PN is defined as a moral obligation to perform or refrain from specific actions [36]. The second, awareness of consequences (AC), refers to whether someone is aware of the negative consequences for others, or for other things one values, when not acting pro-socially. The third, the ascription of responsibility (AR), is described as feelings of responsibility for the negative consequences of not acting pro-socially. Specifically, a PN is an intermediary variable, and social norms are moderating variables. In practice, AC and AR can affect farmers' OFABs by activating PNs under the regulation of social norms. That is, the influence of PNs on farmers' OFABs is mainly realized through two paths. The first path is where the AC and AR first affect PNs and then affect farmers' OFABs under the adjustment of social norms. The second path is where the AC and AR directly affect farmers' OFABs. The following part first analyzes the direct impact of AC and AR on farmers' OFABs. Then, the mediating effect of PNs and the moderating effect of social norms are analyzed.

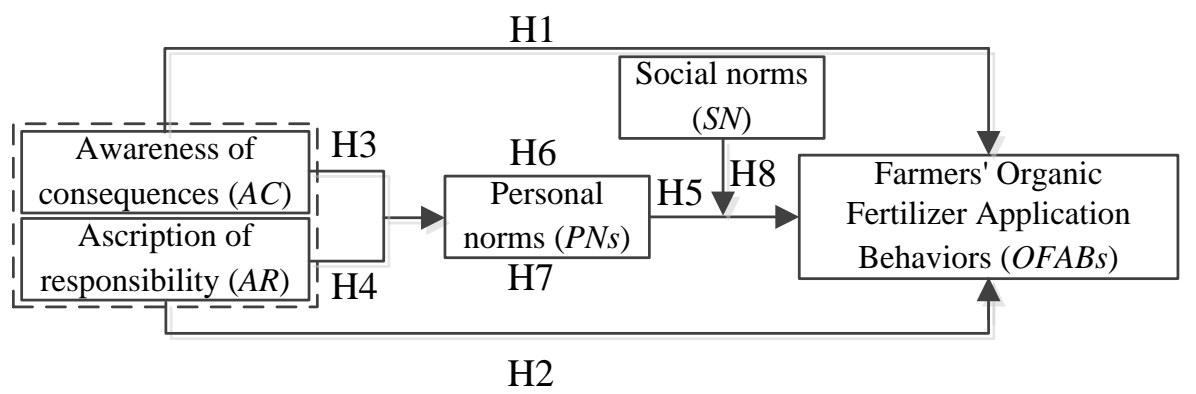

Figure 1. The impact mechanism of AC, AR, and PNs on farmers' OFABs under the context of social norms.

\subsection{Direct Effect of $A C$ and AR on Farmers' OFABs}

According to the NAT, two aspects of farmers' subjective responsibility, namely, AC and AR, are important antecedent variables that can significantly shape farmers' OFABs. Specifically, AC is an important cause of pro-environmental behavior [30]. If a person knows that their behavior may result in a negative consequence, they may tend to adjust their actions to avoid destructive effects [37]. An abundance of research points to the importance of AC in evaluating pro-environmental behavior, including recycling behavior [38], energy conservation behavior [34,39], public transportation usage behavior [40], buying behavior (of environmentally friendly products) [32], and choice behavior (of travel mode) [37]. Equally, in the case of farmers' OFABs, one can assume that, if agricultural non-point source pollution is caused by non-OFABs, farmers may be inclined to adopt 
OFABs. Under the effect of AC, farmers, especially those who are well educated and who have strong environmental awareness, will feel guilty if environmental pollution problems are caused during the agricultural production process. When this environmental awareness is internalized into individual behavior, farmers will consciously optimize their agricultural production behaviors, and they will adopt OFABs according to the actual situation. These practices will eventually contribute to reducing environmental damage. Therefore, we assumed that:

\section{Hypothesis 1 (H1). AC has a direct positive effect on farmers' OFABs.}

AR is also a significant determinant of farmers' OFABs. If a person thinks that everyone should be responsible for the consequences of their actions, that person is likely to practice responsible behavior [41]. Numerous studies have demonstrated that AR plays an important role in shaping individuals' pro-environmental behavior in different environments. Examples of such behavior include reducing car use [34] and attending eco-smart meetings [42]. Similarly, in the case of farmers adopting OFABs, the farmers' AR will also impose certain restrictions on their production behaviors. If a farmer considers that humans have a responsibility to conserve the ecosystem, that farmer may tend to implement OFABs, instead of chemical fertilizers. The stronger the farmers' AC and AR for environmental pollution, the more likely they will be to adopt OFABs. Therefore, this paper proposes the following research hypothesis:

Hypothesis 2 (H2). AR has a direct positive effect on farmers' OFABs.

\subsection{Analysis of the Mediating Effect of PNs}

\subsubsection{The Effect of the AC and AR on Farmers' PNs}

According to Schwartz [30], the NAT proposes three prior factors to predict pro-social behavior (i.e., AC, AR, and PN) [36]. In this context, farmers' PNs refer to farmers' belief that they have both a responsibility and an obligation to apply organic fertilizers in agricultural production. Within the NAT, norm activation is initiated with an individual's awareness of potentially harmful outcomes, as well as AR for practicing non-environmentally friendly behavior. AC and AR will activate the PNs [30] that decide whether one should take specific actions to avoid detrimental consequences [31,34]. Farmers' awareness of nonenvironmental behavior is the prerequisite for the formation of PNs concerning applying organic fertilizers. The more clearly farmers are aware of the consequences of non-OFABs, the stronger the sense of responsibility for the negative consequences of non-OFABs, and the more helpful and more likely this awareness will be in assisting in the formation of PNs for applying organic fertilizers. In summary, this paper proposes the following research hypotheses:

Hypothesis 3 (H3). AC has a positive impact on farmers' PNs.

Hypothesis 4 (H4). AR has a positive impact on farmers' PNs.

\subsubsection{The Influence of PNs on Farmers' OFABs}

According to the NAT, a PN is first activated by both AC and AR, which then have a direct effect on individual behaviors $[30,34]$, including various pro-environmental behaviors $[43,44]$. If the PN prescribes action, an individual tends to take that action to avoid the foreseeable detrimental outcomes [31]. The clearer farmers' awareness of the consequences of non-OFABs, the stronger the sense of responsibility for the negative consequences of non-OFABs, and the more likely that sense of responsibility will lead to the formation of PNs for their OFABs. Ultimately, this will all lead to a higher possibility of farmers applying organic fertilizers. In other words, when a PN related to the application of organic fertilizers by farmers is activated, any non-application of organic fertilizers may induce negative emotions (e.g., guilt or self-blame) in farmers. These feelings will further 
encourage farmers to adopt organic fertilizer application and other environmental behaviors in the agricultural production process. Therefore, this paper proposes the following research hypothesis:

Hypothesis 5 (H5). PNs have a positive influence on farmers' OFABs.

\subsubsection{Analysis of the Mediating Effect of PNs}

According to the NAT and the above analysis, the indirect influence path of farmers' AC and AR for their OFABs is mainly through the activation of farmers' PNs. Additionally, PNs related to organic fertilizer application will be internalized. Some scholars have discovered that high AC strengthens the influence of PNs on pro-environmental behavior [45-47]. The code of conduct and norms strengthen the sense of responsibility and obligation to implement environmentally friendly and pro-environmental behaviors in the agricultural production process, thereby increasing farmers' willingness to apply organic fertilizers and ultimately increasing the possibility of farmers applying organic fertilizers. Therefore, this paper proposes the following research hypotheses:

Hypothesis 6 (H6). PNs have a mediating effect on the relationship between AC and farmers' OFABs.

Hypothesis 7 (H7). PNs have a mediating effect on the relationship between AR and farmers' OFABs.

\subsection{Analysis of the Moderating Effect of Social Norms}

Several scholars have advised that farmers' behavior can be changed by economic motivation and external environmental factors, such as formal regulations, suggestions, and collective activities [48,49]. The NAT is used in the specific situation of China's agricultural production, as well as in improving the applicability of farmers' OFABs. Therefore, the NAT needs to be expanded [42]. Farmers' OFABs are also restricted by a variety of external conditions. Social norms are often examined in studies related to environmental decision-making processes and behaviors [50-53]. Therefore, this study incorporated social-environmental factors (e.g., social norms) into the NAT framework, in order to examine farmers' OFABs. The term "social norms" refers to the perceived social pressure to perform or not to perform a behavior [54]. These variables are usually contained in theoretical studies derived from pro-social motivation (e.g., NAT) $[53,55,56]$. However, these studies usually present paradoxical results on the function of social norms in the NAT; the findings reveal that individual perceived social pressure is closely related to some variables within the NAT framework $[52,53,55,56]$.

As mentioned above, the importance of social norms in environmental decision making is not only frequently emphasized in the expected value literature $[50,51]$ but also in studies regarding virtually any theory based on pro-social motivation [52,53]. In the context of farmers' OFABs, the term "social norms" refers to the rules and standards that farmers perceive regarding the application of organic fertilizers by other farmers in the usual agricultural production process. PNs related to organic fertilizer application stimulate the real behavior of farmers, and the social norms of farmers that are related to the application of organic fertilizers are mainly social pressure. This pressure will promote the effect of PNs on farmers' OFABs. The stronger the social norms that farmers perceive, the more significant the effect of PNs in promoting their OFABs. Thus, this research proposes the following hypothesis:

Hypothesis 8 (H8). Social norms have a moderating effect between PNs and farmers' OFABs. 


\section{Data Sources, Variable Settings, and Model Selection}

\subsection{Data Sources}

The data for this paper were obtained from data collected by the research team in a field survey. We had 13 enumerators in total. The survey adopted a combination of stratified random sampling and simple random sampling, combined with semi-structured interviews. We first conducted stratified sampling of Hubei Province according to the topography and the level of social and economic development, obtaining Wuhan city and Tianmen city in the plain areas, and Jingmen city and Huangshi city in the hilly areas, and then based on the number of rural populations in each city and the rural population share. For the proportion, 1-2 counties (districts) were selected from each prefecture and city. Specifically, due to the rural population in Jingmen city (1.74 million) and the proportion of the rural population in the total population $(60 \%)$, it is higher in these four cities ${ }^{1}$. We selected two counties (cities) in Jingmen city, and one county (city) in Wuhan city, Huangshi city, and Tianmen city. Finally, we chose Huangpi District in Wuhan city, Zhongxiang city, and Jingshan city in Jingmen City, Daye city in Huangshi city, and Tianmen city as the survey areas. These survey areas include plains and mountainous areas, which are typical and representative in terms of regional location and economic level characteristics.

The research team conducted a questionnaire survey of some farmers in these five counties (cities, districts) in Central China. The field survey was conducted in November 2019. To ensure the representativeness and effectiveness of the survey, a stratified random sampling method was used to obtain the sample area for the study, the questionnaires were revised and optimized through a pre-survey, and the investigators were trained. We used a multi-stage stratified random sampling method to determine specific survey points. First, we selected 2-3 townships in each district (city) based on the characteristics, area, population, and the number of administrative villages in different districts (city). In the second stage, two to three administrative villages were randomly selected from each township. In the third stage, according to the population and size of the village, 10-20 farmers were selected randomly in each administrative village for conducting a questionnaire survey. Only the head of the household or family farming decision-maker was allowed to participate in the survey. The members of the investigation team received training and obtained relevant information from the interviewees through face-to-face interviews, either at home or in the field. The contents of this survey mainly include individual characteristics, household characteristics, local socio-economic characteristics, PNs and social norms, and rural households' OFABs. In the end, a total of 430 questionnaires were distributed, and after review and screening, and excluding invalid questionnaires, a total of 391 valid sample questionnaires were obtained, and the response rate of farmer samples was $90.93 \%$. Specifically, 88 were from Wuhan city, 115 were from Jingmen city, 112 were from Huangshi city, and 76 were from Tianmen city. All recovered sample questionnaires were archived after inspection, audit, and sorting by the research team, and sample data files were established.

\subsection{Variable Settings}

Based on the theoretical analysis and existing literature $[31,32,35,53,57]$, to meet the requirements of this study, we modified or created new development measures for our study. A scale was designed based on valid and sufficiently reliable evidence from current studies. Modified or new development measures were modeled based on the structure of prior suitable scales [31]. In this study, farmers' OFABs refer to the measures taken by farmers in the process of agricultural production by way of applying their farm manure $[20,58]$ and commercial organic fertilizers [59]. Measurement items were used to measure farmers' $\mathrm{AC}, \mathrm{AR}, \mathrm{PNs}$, and social norms. The items of AC, AR, and PNs were mainly adapted from Onwezen et al. [32], and Tanner and Wölfing Kast [60]. The items of social norms were adapted from Cialdini et al. [61]. All are measured using a 5-point Likert scale, with items ranging from 1 (strongly disagree) to 5 (strongly agree). Detailed item information is shown in Table 1. 
Table 1. Assignment of relevant variables of sample farmers.

\begin{tabular}{|c|c|c|c|c|}
\hline Variable & Measurement Item & $\begin{array}{c}\text { Source of Measurement } \\
\text { Scales }\end{array}$ & $\begin{array}{l}\text { Mean } \\
\text { Value }\end{array}$ & $\begin{array}{l}\text { Standard } \\
\text { Deviation }\end{array}$ \\
\hline \multirow[t]{2}{*}{$\begin{array}{l}\text { Farmers' organic } \\
\text { fertilizer application } \\
\text { behaviors }(O F A B s)\end{array}$} & $\begin{array}{l}\text { Should farmers use their farm manure } \\
\left(\mathrm{OFABs}_{1}\right) \text {, such as plant straw, livestock, } \\
\text { and poultry manure? Yes }=1, \text { no }=0 \text {. }\end{array}$ & $\begin{array}{l}\text { Ma et al. [59]; } \\
\text { Wang et al. [20]; } \\
\text { Lal et al. (2020) }\end{array}$ & 0.278 & 0.448 \\
\hline & $\begin{array}{c}\text { Should farmers use commercial organic } \\
\text { fertilizer }\left(\mathrm{OFABs}_{2}\right) \text {, such as earthworm } \\
\text { organic fertilizer, and other biological } \\
\text { fertilizers? Yes }=1, \text { no }=0 .\end{array}$ & Ma et al. (2018) & 0.117 & 0.323 \\
\hline \multirow[t]{3}{*}{$\begin{array}{c}\text { Awareness of } \\
\text { consequences }(A C)\end{array}$} & $\begin{array}{c}\text { Not applying organic fertilizers will } \\
\text { degrade the soil quality }\left(\mathrm{AC}_{1}\right) . \text { Totally } \\
\text { disagree }=1 ; \text { disagree }=2 ; \text { neither agree nor } \\
\text { disagree }=3 \text {; agree }=4 ; \text { totally agree }=5 \text {. }\end{array}$ & Onwezen et al. [32] & 3.376 & 0.729 \\
\hline & $\begin{array}{c}\text { Not applying organic fertilizers will cause } \\
\text { agricultural environmental pollution }\left(\mathrm{AC}_{2}\right) \\
\text { Totally disagree }=1 \text {; disagree }=2 \text {; neither } \\
\text { agree nor disagree }=3 \text {; agree }=4 \text {; totally } \\
\text { agree }=5 .\end{array}$ & Onwezen et al. [32] & 3.462 & 0.704 \\
\hline & $\begin{array}{c}\text { Not applying organic fertilizers will restrict } \\
\text { the sustainable development of agriculture } \\
\left(\mathrm{AC}_{3}\right) . \text { Totally disagree }=1 ; \text { disagree }=2 ; \\
\text { neither agree nor disagree }=3 ; \text { agree }=4 ; \\
\text { totally agree }=5 \text {. }\end{array}$ & Onwezen et al. [32] & 3.348 & 0.706 \\
\hline \multirow[t]{3}{*}{$\begin{array}{l}\text { Ascription of } \\
\text { responsibility }(A R)\end{array}$} & $\begin{array}{c}\text { Do you feel responsible for the deterioration } \\
\text { of soil quality caused by not applying } \\
\text { organic fertilizers }\left(\mathrm{AR}_{1}\right) \text { ? Totally disagree = } \\
\begin{array}{c}\text {; disagree }=2 ; \text { neither agree nor disagree }= \\
3 ; \text { agree }=4 \text {; totally agree }=5 .\end{array}\end{array}$ & Onwezen et al. [32] & 3.002 & 0.839 \\
\hline & $\begin{array}{l}\text { Do you feel responsible for the agricultural } \\
\text { environmental pollution caused by not } \\
\text { applying organic fertilizers }\left(\mathrm{AR}_{2}\right) \text { ? Totally } \\
\text { disagree }=1 \text {; disagree }=2 ; \text { neither agree nor } \\
\text { disagree }=3 \text {; agree }=4 ; \text { totally agree }=5 .\end{array}$ & Onwezen et al. [32] & 3.013 & 0.837 \\
\hline & $\begin{array}{l}\text { Do you feel responsible for the restriction of } \\
\text { not applying organic fertilizers to the } \\
\text { sustainable development of agriculture } \\
\left(\mathrm{AR}_{3}\right) \text { ? Totally disagree }=1 \text {; disagree }=2 ; \\
\text { neither agree nor disagree }=3 \text {; relatively } \\
\text { agree }=4 \text {; totally agree }=5 \text {. }\end{array}$ & Onwezen et al. [32] & 3.026 & 0.816 \\
\hline \multirow[t]{2}{*}{ Personal norms $(P N s)$} & $\begin{array}{c}\text { Do you think you should use organic } \\
\text { fertilizer and other environmental } \\
\text { behaviors }\left(\mathrm{PN}_{1}\right) \text { ? Totally disagree }=1 ; \\
\text { disagree }=2 ; \text { neither agree nor disagree }=3 ; \\
\text { agree }=4 ; \text { totally agree }=5 \text {. }\end{array}$ & $\begin{array}{l}\text { Onwezen et al. [32]; Tanner } \\
\text { and Wölfing Kast [60] }\end{array}$ & 3.545 & 0.681 \\
\hline & $\begin{array}{l}\text { Do you think you are responsible for using } \\
\text { organic fertilizers and other environmental } \\
\text { behaviors }\left(\mathrm{PN}_{2}\right) \text { ? Totally disagree }=1 ; \\
\text { disagree }=2 \text {; neither agree nor disagree }=3 \text {; } \\
\text { relatively agree }=4 \text {; totally agree }=5 \text {. } \\
\text { Do you feel guilty if you do not use organic } \\
\text { fertilizers and other environmental } \\
\text { behaviors }\left(\mathrm{PN}_{3}\right) \text { ? Totally disagree }=1 ; \\
\text { disagree }=2 ; \text { neither agree nor disagree }=3 ; \\
\text { agree }=4 \text {; totally agree }=5 .\end{array}$ & $\begin{array}{l}\text { Onwezen et al. [32]; Tanner } \\
\text { and Wölfing Kast [60] }\end{array}$ & 3.179 & 0.754 \\
\hline
\end{tabular}


Table 1. Cont.

\begin{tabular}{|c|c|c|c|c|}
\hline Variable & Measurement Item & $\begin{array}{c}\text { Source of Measurement } \\
\text { Scales }\end{array}$ & $\begin{array}{l}\text { Mean } \\
\text { Value }\end{array}$ & $\begin{array}{l}\text { Standard } \\
\text { Deviation }\end{array}$ \\
\hline & $\begin{array}{l}\text { Do you feel guilty if you do not use organic } \\
\text { fertilizers and other environmental } \\
\text { behaviors }\left(\mathrm{PN}_{3}\right) \text { ? Totally disagree }=1 ; \\
\text { disagree }=2 ; \text { neither agree nor disagree }=3 ; \\
\text { agree }=4 ; \text { totally agree }=5 .\end{array}$ & $\begin{array}{l}\text { Onwezen et al. [32]; Tanner } \\
\text { and Wölfing Kast [60] }\end{array}$ & 3.179 & 0.754 \\
\hline \multirow[t]{3}{*}{ Social norms (SNs) } & $\begin{array}{l}\text { Do you think relatives will use organic } \\
\text { fertilizers and implement other } \\
\text { environmental behaviors }\left(\mathrm{SN}_{1}\right) \text { ? Totally } \\
\text { disagree }=1 ; \text { disagree }=2 ; \text { neither agree nor } \\
\text { disagree }=3 \text {; agree }=4 \text {; totally agree }=5 \text {. }\end{array}$ & Cialdini et al. [61] & 3.205 & 1.189 \\
\hline & $\begin{array}{l}\text { Do you think friends will use organic } \\
\text { fertilizers and implement other } \\
\text { environmental behaviors }\left(\mathrm{SN}_{2}\right) \text { ? Totally } \\
\text { disagree }=1 ; \text { disagree }=2 ; \text { neither agree nor } \\
\text { disagree }=3 \text {; agree }=4 \text {; totally agree }=5 \text {. }\end{array}$ & Cialdini et al. [61] & 3.133 & 0.639 \\
\hline & $\begin{array}{l}\text { Do you think neighbors will use organic } \\
\text { fertilizers and implement other } \\
\text { environmental behaviors }\left(\mathrm{SN}_{3}\right) \text { ? Totally } \\
\text { disagree }=1 \text {; disagree }=2 ; \text { neither agree nor } \\
\text { disagree }=3 \text {; agree }=4 \text {; totally agree }=5 \text {. }\end{array}$ & Cialdini et al. [61] & 3.046 & 0.749 \\
\hline
\end{tabular}

\subsection{Analytical Method}

Based on the above theoretical analysis and the conclusions of the existing literature, because the PLS method does not require a large sample size, the data do not need to obey a multivariate normal distribution; the data are also allowed to have features such as collinearity. Currently, there are two diverse SEM methods: partial least squares (PLS-SEM) and co-variance based [62]. The characteristics of the PLS-SEM method matched the sample size of this study. Hence, PLS-SEM was considered as the most suitable method to assess the results in this study, just as suggested by Hair Jr et al. [62]. Thus, this paper adopted a structural equation model (SEM) for empirical analysis. An SEM is mainly used to establish a specific causal model for the assumed causal relationship between the observed variables, including the measurement model and structural model. The measurement model reflects the relationship between the latent variables and the observed variables. In the measurement model, the latent variables can be defined by the observed variables; the structural model represents the relationship between the latent variables. The equations of the measurement model and structural model and their meanings are as follows:

Measurement model: $X=\Lambda_{X} \xi+\delta$

$$
Y=\Lambda_{Y} \eta+\varepsilon
$$

Structural model: $\eta=B \eta+\Gamma \xi+\zeta$

Specifically, $\xi$ and $\eta$ are the exogenous latent variables and endogenous latent variables, respectively, $X$ is the observed variable of $\xi, Y$ is the observed variable of $\eta, \Lambda_{X}$ is the coefficient connecting variable $X$ and variable $\xi, \Lambda_{Y}$ is the coefficient connecting variable $Y$ and variable $\eta, \delta$ and $\varepsilon$ are the error terms of the $X$ and $Y$ variables, respectively; $B$ represents the regression coefficients of the variables, $\eta$ and $\Gamma$ are the regression coefficients of the $\xi$ variables on the $\eta$ variables, and $\zeta$ is the error term of $\eta$. 


\section{Empirical Analysis}

\subsection{Reliability and Validity Test}

\subsubsection{Reliability Test}

This paper used the internal consistency reliability coefficient (Cronbach's $\alpha$ value) and the internal consistency of the latent variables in the composite reliability measurement model. Using Smart PLS 3.0 software for reliability analysis, the reliability test results of latent variables are shown in Table 2. As it can be seen from Table 2, the Cronbach's $\alpha$ value of each latent variable is higher than 0.6 , and the combined reliability (CR) value of each factor (latent variable) is higher than 0.8. These findings show that the internal consistency of the scale is good, and the measurement model's construct reliability is good. Therefore, the questionnaire used in this study is highly reliable.

Table 2. Convergence validity analysis results.

\begin{tabular}{|c|c|c|c|c|c|c|c|}
\hline Latent Variable & Indicator & Value of $\alpha$ & C.R. & $\begin{array}{c}\text { Standardized Factor } \\
\text { Loading }\end{array}$ & AVE & KMO & $\begin{array}{c}\text { Bartlett Sphericity } \\
\text { Test }\end{array}$ \\
\hline \multirow{4}{*}{$\begin{array}{l}\text { Ascription of } \\
\text { responsibility (AR) }\end{array}$} & $\mathrm{AR}_{1}$ & 0.987 & 0.991 & 0.988 & 0.975 & 0.755 & 0.000 \\
\hline & $\mathrm{AR}_{2}$ & & & 0.990 & & & \\
\hline & $\mathrm{AR}_{3}$ & & & 0.972 & & & \\
\hline & $\mathrm{PN}_{1}$ & 0.875 & 0.922 & 0.872 & 0.797 & 0.680 & 0.000 \\
\hline \multirow[t]{2}{*}{ Personal norms (PNs) } & $\mathrm{PN}_{2}$ & & & 0.930 & & & \\
\hline & $\mathrm{PN}_{3}$ & & & 0.869 & & & \\
\hline \multirow{5}{*}{$\begin{array}{c}\text { Organic fertilizer } \\
\text { application behaviors } \\
\text { (OFABs) } \\
\text { Awareness of } \\
\text { consequences (AC) }\end{array}$} & $\mathrm{OFABs}_{1}$ & 0.650 & 0.848 & 0.918 & 0.737 & 0.500 & 0.000 \\
\hline & $\mathrm{OFABs}_{2}$ & & & 0.863 & & & \\
\hline & $\mathrm{AC}_{1}$ & 0.671 & 0.813 & 0.720 & 0.591 & 0.577 & 0.000 \\
\hline & $\mathrm{AC}_{2}$ & & & 0.776 & & & \\
\hline & $\mathrm{AC}_{3}$ & & & 0.701 & & & \\
\hline
\end{tabular}

\subsubsection{Validity Test}

With the help of Smart PLS 3.0 and SPSS20.0 software, factor loading and average variance extraction (AVE) were used to test the convergence validity. One can see that, in Table 2, the Kaiser-Meyer-Olkin (KMO) statistical values of the corresponding subscales of each latent variable are all above 0.5 , and the significance level of the test results is less than 0.001 . These findings show that the research scale is suitable for factor analysis. In this study, the standardized factor loading value of each variable is greater than 0.7 , and the AVE of each factor (latent variable) is greater than 0.5 . This indicates that each latent variable has good convergence validity. Moreover, this study further used the AVE value to test the discriminative validity. If the square root of the AVE value of each variable is greater than the absolute value of the correlation coefficient between it and other variables, the variables can be considered to have good discriminative validity. The results of the discriminative validity analysis are shown in Table 3. The square root of the AVE of each latent variable in Table 3 is significantly higher than the absolute value of its correlation coefficient with other variables. This means that the model variables have better discriminative validity. Therefore, on the whole, each variable of the model has good convergence validity and discriminative validity.

Table 3. Results of the discriminative validity test.

\begin{tabular}{ccccc}
\hline Variable & AR & AC & PNs & OFABs \\
\hline AR & 0.987 & & & \\
AC & 0.418 & 0.769 & & \\
PNs & 0.634 & 0.487 & 0.893 & 0.858 \\
OFABs & 0.388 & 0.122 & 0.326 & \\
\hline
\end{tabular}




\subsection{Model Fitness and Hypothesis Testing}

\subsubsection{Model Fitness Test}

The reliability and validity analysis results of each latent variable show that the research is suitable for structural equation analysis. This paper used survey data of farmers in Hubei Province to calculate the model fitness of the factors that affect farmers' OFABs (Table 4). The normed fit index (NFI) value of 0.815 can meet the needs, which shows that the model fitness is relatively ideal. The initial theoretical model can be used as the final accepted model.

Table 4. Test results of model fitness.

\begin{tabular}{ccc}
\hline Statistical Test Index & Model & Judgment Standard \\
\hline NFI & 0.815 & $>0.8$ \\
\hline
\end{tabular}

\subsubsection{Structural Equation Model Estimation Results}

In this study, Smart PLS 3.0 software was used to analyze the farmers' OFABs by the structural equation model. The results are shown in Table 5 and Figure 2. According to the theoretical analysis results, the empirical analysis is mainly divided into three parts:

(1) The effect of AC and AR on farmers' OFABs. From Table 5, on the one hand, the path coefficient between AC and farmers' OFABs is -0.094 , and the $p$-value is 0.107 . The relationship between them is not significant (but close to the $10 \%$ significance level). The result indicates that $\mathrm{AC}$ has a certain effect on farmers' OFABs. The direct effect of AC on farmers' OFABs is not significant, meaning hypothesis $\mathrm{H} 1$ is not confirmed. This may be because farmers' awareness of using organic fertilizers requires certain conditions before being transformed into OFABs. Although OFABs can improve soil conditions and the ecological environment, this behavior also means a reduction in crop yields and an increase in labor [63]. The decrease in income does not motivate farmers who rely on agricultural income to apply organic fertilizers. This leads to the AC not being effectively transformed into OFABs. On the other hand, the path coefficient between AR and farmers' OFABs is 0.320 , and the $p$-value is less than 0.01 . The relationship between them is significantly positive, which means that AR has a direct positive impact on farmers' OFABs. This result is in line with the expectations, meaning $\mathrm{H} 2$ is confirmed.

Table 5. Structural equation model estimation results.

\begin{tabular}{cccccc}
\hline Hypothetical Test & Path & Estimate & S.D. & $p$-Value & Conclusion \\
\hline H1 & Awareness of consequences (AC) OFABs & -0.094 & 0.058 & 0.107 & Non-support \\
H2 & $\begin{array}{c}\text { Ascription of responsibility (AR) OFABs } \\
\text { Awareness of consequences (AC) Personal } \\
\text { norms (PNs) }\end{array}$ & $0.320^{* * *}$ & 0.072 & 0.000 & $0.269 * * *$ \\
H3 & Ascription of responsibility (AR) Personal & 0.054 & 0.000 & Support \\
H4 & norms (PNs) & $0.522 * * *$ & 0.051 & 0.000 & Support \\
H5 & Personal norms (PNs) OFABs & $0.169 * *$ & 0.070 & 0.015 & Support \\
\hline
\end{tabular}

Note: ${ }^{* * *}$ and ${ }^{* *}$ indicate significance at the levels of 0.01 and 0.05 , respectively. S.D. = standard deviation.

(2) The impact of AC and AR on farmers' PNs: From Table 5, we know that the path coefficients between AC and PNs and between AR and PNs are 0.269 and 0.522, respectively; all of them also passed the significance test at the $1 \%$ level. This shows that the deeper the farmers' understanding of the harmfulness of not utilizing organic fertilizers, and the stronger their AR for using organic fertilizers, the more likely they are to transform their awareness of applying organic fertilizers into their codes of conduct, and the more they can improve their standards of applying organic fertilizers. We also know that both AC and AR can effectively activate and promote farmers' PNs. Therefore, H3 and H4 are confirmed. 


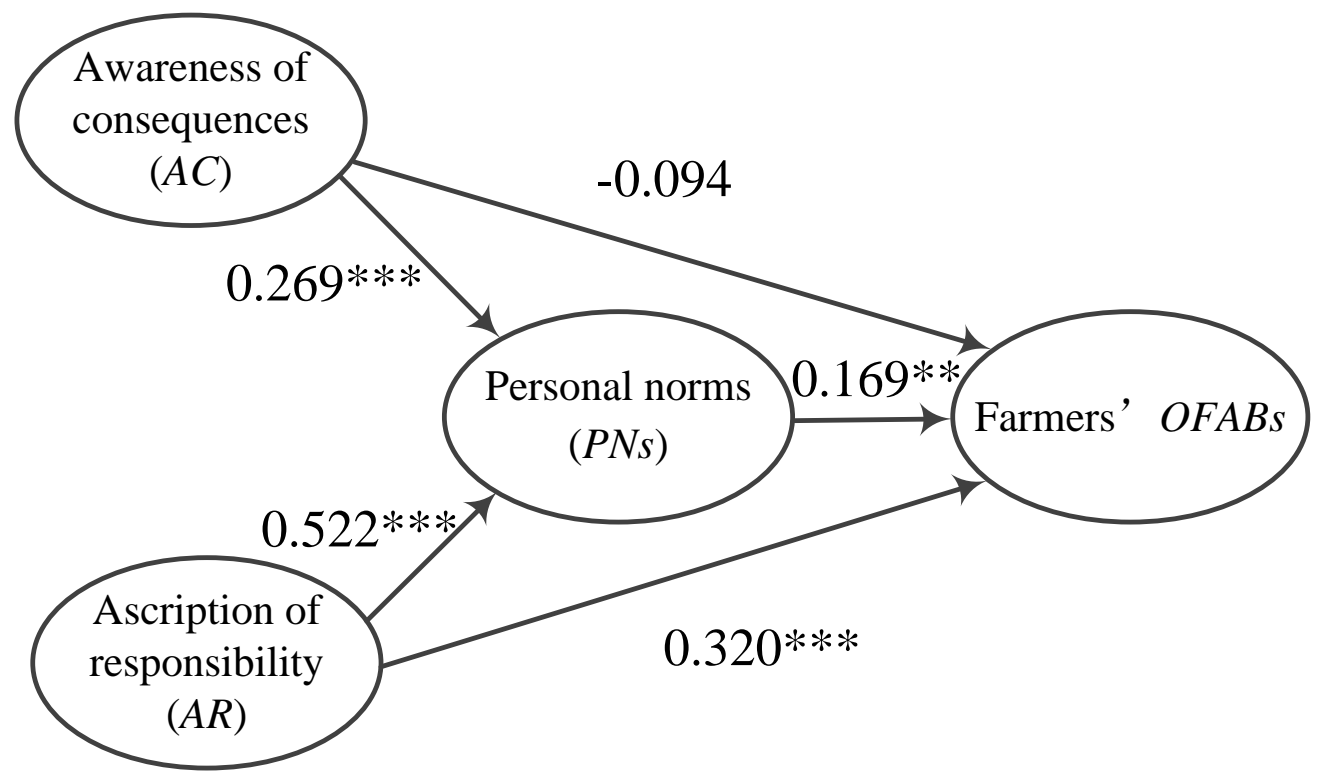

Figure 2. Model path and estimated parameter results. Note: ${ }^{* *}$ and ${ }^{* *}$ indicate significance at the levels of 0.01 and 0.05 , respectively.

(3) The influence of PNs on farmers' OFABs: The path coefficient of PNs on farmers' OFABs is 0.169 and is significant under $5 \%$ confidence. This shows that the higher the PN of utilizing organic fertilizers, the stronger the willingness of farmers to apply organic fertilizers, and the more helpful the farmers will feel when purchasing and using organic fertilizer products. Therefore, H5 is confirmed, which is consistent with the current results [35,40]. Moreover, combined with the confirmed H3 and H4 in Part (2), we know that $\mathrm{AC}$ and $\mathrm{AR}$ can significantly promote the implementation of farmers' OFABs via PNs. Thus, $\mathrm{H} 6$ and $\mathrm{H} 7$ are confirmed.

To further explore the direct effects, indirect effects, and total effects among the latent variables in the structural model, this paper summarizes the calculation results in Table 6. From this table, we know that the variable that has the greatest impact on farmers' OFABs is the farmers' AR (0.408). This is followed by PNs (0.169) and, finally, AC (0.046). The variable that has the greatest impact on farmers' PNs is AR (0.522), followed by AC (0.269). Therefore, compared with AC, AR can more effectively improve farmers' OFABs and PNs. To promote the application of organic fertilizers by farmers, the most important thing is to improve farmers' AR and PNs.

Table 6. Estimation results of the structural equation model.

\begin{tabular}{ccccc}
\hline $\begin{array}{c}\text { Hypothetical } \\
\text { Test }\end{array}$ & \multicolumn{1}{c}{ Path } & Direct Effect & $\begin{array}{c}\text { Indirect } \\
\text { Effect }\end{array}$ & Total Effect \\
\hline $\mathrm{H} 1$ & $\begin{array}{c}\text { Awareness of consequences } \\
\text { (AC) OFABs }\end{array}$ & -0.094 & $0.046^{* *}$ & $0.046^{* *}$ \\
$\mathrm{H} 2$ & $\begin{array}{c}\text { Ascription of responsibility } \\
\text { (AR) OFABs }\end{array}$ & $0.320^{* * *}$ & $0.088^{* *}$ & $0.408^{* *}$ \\
$\mathrm{H} 3$ & $\begin{array}{l}\text { Awareness of consequences } \\
\text { (AC) Personal norms (PNs) }\end{array}$ & $0.269^{* * *}$ & - & $0.269^{* * *}$ \\
$\mathrm{H} 4$ & $\begin{array}{c}\text { Ascription of responsibility } \\
\text { (AR) Personal norms (PNs) }\end{array}$ & $0.522^{* * *}$ & - & $0.522^{* * *}$ \\
$\mathrm{H} 5$ & $\begin{array}{c}\text { Personal norms (PNs) OFABs } \\
\text { A }\end{array}$ & $0.169^{* *}$ & - & $0.169^{* *}$
\end{tabular}

Note: *** and ${ }^{* *}$ indicate significance at the levels of 0.01 and 0.05 , respectively. Total effect $=$ direct effect + indirect effect, such as indirect effect of consciousness $=0.269 \times 0.169=0.046$. 


\subsection{Grouped Structural Equation Test}

Multi-group SEM analysis is used to assess whether a model that fits a certain sample is also suitable for other different samples $[64,65]$. Whether the hypothesis model proposed by the researcher is equal among different samples or whether the parameters are invariant can also be assessed. This multi-group analysis used regional differences and industry integration variables as categorical variables and was conducted on the total sample. The final estimated results from the multi-group analysis are shown in Table 7, after a series of tests.

Table 7. Grouping test estimation results of different regions and industrial characteristics.

\begin{tabular}{|c|c|c|c|c|c|c|}
\hline \multirow[b]{2}{*}{ Path } & \multicolumn{3}{|c|}{ Plain Households $(n=231)$} & \multicolumn{3}{|c|}{ Mountain Households $(n=160)$} \\
\hline & $\begin{array}{c}\text { Path } \\
\text { Coefficient }\end{array}$ & $p$-Value & Conclusion & $\begin{array}{c}\text { Path } \\
\text { Coefficient }\end{array}$ & $p$-Value & Conclusion \\
\hline AC OFABs & -0.088 & 0.275 & Non-support & -0.142 & 0.184 & Non-support \\
\hline AR OFABs & $0.350 * * *$ & 0.000 & Support & 0.294 * & 0.062 & Support \\
\hline AC PNs & $0.364^{* * *}$ & 0.000 & Support & $0.182 *$ & 0.058 & Support \\
\hline AR PNs & $0.553^{* * *}$ & 0.000 & Support & $0.586^{* * *}$ & 0.000 & Support \\
\hline PNs OFABs & $0.189^{* *}$ & 0.035 & Support & 0.146 & 0.233 & Non-support \\
\hline \multirow{2}{*}{ Path } & \multicolumn{3}{|c|}{ Integration households $(n=116)$} & \multicolumn{3}{|c|}{ Non-integration households $(n=275)$} \\
\hline & Path coefficient & $p$-value & Conclusion & Path coefficient & $p$-value & Conclusion \\
\hline AC OFABs & -0.148 & 0.142 & Non-support & -0.072 & 0.338 & Non-support \\
\hline AR OFABs & $0.494^{* *}$ & 0.020 & Support & $0.222 * *$ & 0.022 & Support \\
\hline AC PNs & $0.315^{* * *}$ & 0.000 & Support & $0.261^{* * *}$ & 0.000 & Support \\
\hline AR PNs & $0.445^{* * *}$ & 0.000 & Support & $0.592^{* * *}$ & 0.000 & Support \\
\hline PNs OFABs & 0.053 & 0.613 & Non-support & $0.247^{* * *}$ & 0.005 & Support \\
\hline
\end{tabular}

Note: $n$ is the sample size; ${ }^{* * *}, * *$, and ${ }^{*}$ indicate significance at the levels of $0.01,0.05$, and 0.10 , respectively.

Compared with the outcomes, the analysis results of the grouped samples (Table 7) and the total samples (Table 5) are similar. These results further show that the research results are relatively robust. They show that farmers from different regions and different industry integration areas have relatively small differences in terms of the application of organic fertilizers. The main difference is that the direct influence of PNs of the mountainous samples and the industrial fusion samples on farmers' OFABs did not pass the significance test. One possible explanation is that, on the one hand, the numbers of mountainous samples and industry integration samples are relatively small (160 and 116, respectively) and thereby failed to obtain a significant impact. On the other hand, the proportion of sample farmers in mountainous areas who apply organic fertilizers was relatively high (the proportion of farmers in mountainous areas applying organic fertilizers was $27.5 \%$; the proportion of industry integration sample farmers applying organic fertilizers was $27.6 \%$ ). The studied farmers have a strong awareness of the importance of applying organic fertilizers, which leads to the failure of PNs to effectively promote farmers' use of organic fertilizers.

\subsection{Moderating Effect Test}

This study used STATA15.0 software to perform a hierarchical regression analysis, in order to verify the moderating role of social norms in the process of transforming PNs of applying organic fertilizers to OFABs. In this part, the average value of each item under the three variables of PNs, social norms, and OFABs is incorporated into the model for analysis. When analyzing the regulating effect of social norms, they are first substituted into the regression model to obtain Model 1 and Model 2. Then, the interaction terms of PNs and social norms of organic fertilizer application by farmers are incorporated into Model 3 (Table 8). If the coefficient of determination in Model 3 is significantly higher than that in Models 1 and 2, or if the regression coefficient of the interaction term between PNs 
and social norms in Model 3 passes the significance test, this indicates that social norms function as a moderating effect between PNs and OFABs. From Table 6, the coefficient of determination in Model 3 is higher than that in Model 1 and Model 2. The coefficient of the interaction term between PNs and social norms on farmers' OFABs is -0.67 , and the social norms in Model 2 and Model 3 pass Model 1. The significance level of $10 \%$ indicates that social norms have a significant negative regulating effect on the relationship between farmers' PNs and their OFABs. One possible explanation for this finding could be the low level of social norms perceived by the sampled farmers (the average value is 3.13, close to "neither agree nor disagree"). That is, there are fewer relatives, friends, and neighbors applying organic fertilizers; the social pressure from relatives, friends, and neighbors to apply organic fertilizers is not great. The application of organic fertilizers by farmers is easily affected by the behavior of surrounding farmers. To avoid psychological pressure due to differences in behavior, farmers are more inclined to adopt behaviors that are similar to those of surrounding farmers. Therefore, farmers do not have enough motivation to apply organic fertilizers; this is consistent with previous conclusions $[57,66,67]$, which confirms that farmers' behavioral decisions tend to show a herd effect. In summary, this paper believes that $\mathrm{H} 8$ is verified.

Table 8. Test results of the moderating effect.

\begin{tabular}{cccc}
\hline & Model 1 & Model 2 & Model 3 \\
\hline IN & $1.16^{* * *}(0.18)$ & $0.79 * * *(0.21)$ & $2.99 * * *(0.91)$ \\
SN & & $0.71^{* * *}(0.25)$ & $3.29 * * *(1.08)$ \\
IN $\times$ SN & & $-0.67 * *(0.27)$ \\
Pseudo-R ${ }^{2}$ & 0.106 & 0.124 & 0.138 \\
Chi $^{2}$ & 50.15 & 58.92 & 65.38 \\
\hline Note: $^{* * *}$ and ${ }^{* *}$ indicate significance at the levels of 0.01 and 0.05, respectively.
\end{tabular}

\section{Discussion}

\subsection{Theoretical Implications}

This study enriches the research results on pro-environmental behavior in three main aspects. Firstly, a theoretical framework is established to investigate the factors that influence farmers' OFABs in Central China. While governments still experience difficulty in encouraging farmers to adopt OFABs, research on how to encourage farmers' OFABs is still in its infancy, with just very few studies completed to date [68-70]. Moreover, although China is a major fertilizer consumer, research on Chinese farmers' OFABs is still not very common. Secondly, social norms are not conducive to increasing the impact of personal norms on farmers' OFABs. In fact, in the case of high social norms, the impact of personal norms on farmers' OFABs is relatively weak. Existing studies have overlooked the role of this regulator between personal norms and pro-environmental behaviors [71,72]. Additionally, we found that farmers' social norms have a negative moderating impact on personal norms and their OFABs. Thirdly, the concept of personal norms is proposed, and the influence of personal norms on farmers' OFABs is investigated. We observed that personal norms mediate the awareness of consequences, ascription of responsibility, and farmers' OFABs. These results expand our knowledge of how personal norms affect farmers' OFABs. Though the impact of personal norms on pro-environmental behaviors has long been acknowledged $[34,35,39,40]$, its function in motivating farmers' OFABs has still not been examined. Therefore, this study puts forward personal norms and discusses their impact on farmers' OFABs in an empirical way, which is helpful for research in this field.

\subsection{Practical Implications}

This study found that personal norms are the most critical factor affecting farmers' OFABs. These results are in line with prior studies that have recognized the important role of personal norms in pro-environment behaviors [32,35,39,42,52]. They also show that the 
moral obligation of farmers in specific pro-environmental behaviors is crucial to better recognize their pro-environmental behavioral intentions. Making a farmer's personal norms include participating in pro-environmental behaviors is crucial to successfully promoting pro-environmental intentions. These results show that AC and AR play an important and positive role in inspiring personal norms. Having developed a deep understanding of this theoretical mechanism, practitioners should actively seek effective ways to improve the key factors of personal norms. Specifically, existing and potential farmers should be notified through various means of communication of the extent to which environmental damage is caused by non-environmental activities, as well as by personal non-environmental interests. Pro-environmental behaviors help alleviate the damage to the ecological environment. These actions will facilitate farmers' development of high levels of AC and AR, thus raising the personal norms of farmers, which are vital determinants of environmental behaviors.

\subsection{Limitations and Future Research}

Some limitations of this study are worth noting. First, this study only focuses on farmers' OFABs. Other types of agricultural-scale operators, such as agribusinesses, cooperatives, and big grain growers, have not been covered. Large diversities may exist between farmers and these agricultural-scale operators (e.g., in terms of pro-environmental behaviors). Therefore, attempting to generalize the findings of this study to other different groups, especially agricultural-scale operators, is difficult. Future research may emphasize other types of OFABs, such as those of agricultural-scale operators. Second, the survey data come from Hubei, Central China. Due to the disparities between China and other countries, as well as the sample size, extending the findings to other countries should be carried out with caution, especially concerning the West. Specifically, on the one hand, China is a highly collectivist country, while Western nations are individualistic. In such cases, PNs are likely to have a greater impact on individual behavior in Western nations than in China [39]. Future research should include parallel studies in Western nations to verify the cross-cultural effect. On the other hand, although the sample size $(n=391)$ meets the size suggested by Hair Jr et al. [62] when using SEM for maximum likelihood estimation, our sample size is still somewhat small. Future research should expand this model by using a bigger sample when using this framework to analyze other pro-environmental behaviors. Third, future studies should strive to verify our findings in other pro-environmental behaviors (e.g., ecological pesticides, and degradable agricultural films) to increase the applicability of this conceptual model. Future research should also expand this model by including extra critical variables of pro-environmental behaviors (e.g., ecological values, environmental attitudes, conservation intentions) and incorporating them to perfect this model. Specifically, some scholars studying pro-environmental behaviors believe that values, environmental attitudes, and ecological concerns significantly influence pro-environmental intentions and behaviors that are conducive to the environment $[35,73,74]$. Extending this model with these key concepts will increase the explanatory power for pro-environmental behaviors.

\section{Conclusions and Policy Implications}

Based on the perspective of farmers, this paper constructed an analysis framework for the awareness of consequences, ascription of responsibility, and farmers' organic fertilizer application behaviors (OFABs). This study used questionnaire data from farmers in the surrounding cities of Wuhan city, Hubei Province, and used structural equation modeling and moderating effect analysis to study the influencing mechanism. This study finds the following: Firstly, the ascription of responsibility has a significant positive impact on farmers' OFABs. This shows, to a certain extent, that farmers' ascription of responsibility can significantly promote the transformation of agricultural production methods from high-polluting traditional production methods to low-polluting ecological production methods. Secondly, the awareness of consequences and ascription of responsibility have a significant positive impact on farmers' OFABs through their personal norms. This shows, to a certain extent, that farmers' awareness of consequences and ascription of responsi- 
bility can significantly promote the transformation of agricultural production methods from traditional high-consumption production methods to sustainable low-consumption production methods by improving personal norms. Thirdly, farmers' social norms have a positive regulating effect on the relationship between personal norms and OFABs. This also shows, to a certain extent, that ecological environmental satisfaction can promote the transformation of agricultural production methods from traditional high-input production methods to efficient low-input production methods.

Based on the above conclusions, this study provides the following policy enlightenment: (1) We should vigorously enhance farmers' awareness of consequences and ascription of responsibility. Farmers' awareness of consequences and ascription of responsibility can promote the transformation and optimization of farmers' agricultural production methods. This approach is conducive to achieving the transformation and upgrading of farmers agricultural production activities to sustainable, ecological, and environmentally friendly agriculture and can effectively alleviate agricultural ecological environmental problems. In the future, the government should further strengthen the construction of various ecoenvironmental protection organizations, guide and encourage farmers to participate in eco-environmental protection organizations, and improve the environmental awareness and environmental protection awareness of farmers' family members, in order to encourage farmers to choose environmentally friendly production methods. (2) The effect of the awareness of consequences and ascription of responsibility on farmers' personal norms should be enhanced. Grassroots government and agricultural technology departments should ascribe full importance to the role of publicity and guidance, increase the publicity of rural ecological and environmental protection activities, and provide the necessary technical guidance and training. These actions could not only increase farmers' awareness of chemical fertilizers causing environmental pollution but could also promote farmers ${ }^{\prime}$ awareness of environmentally friendly production practices (e.g., using organic fertilizers on the land). The government should increase investment in rural basic education, enhance the awareness of the responsibility of rural residents in terms of environmental protection, comprehensively enhance farmers' awareness of ecological environmental protection, and then guide and encourage farmers to adopt OFABs. (3) The level of farmers' social norms should be improved. The government should carry out vigorous publicity work concerning the ecological protection of cultivated land, strengthen the ecological norms of farmers, and make them aware of the positive externalities of the ecological environmental protection of cultivated land. These steps will enhance farmers' awareness and satisfaction with the improvement in the ecological environment brought about by environmentally friendly production behaviors. Party members, village cadres, and farmers with strong environmental awareness should be encouraged to take the lead in actively applying organic fertilizers. Through public opinion pressure and demonstration effects, under the guidance of herd mentality, more farmers could be guided to use organic fertilizers and thus promote rural ecological protection and ecological civilization construction.

Author Contributions: Conceptualization, J.X.; methodology, J.X.; validation, J.X.; formal analysis, J.X.; data curation, J.X., and Z.G.; writing-original draft preparation, J.X.; writing-review and editing, J.X.; supervision, G.Y. and G.W.; funding acquisition, G.W. All authors have read and agreed to the published version of the manuscript.

Funding: This research was funded by the National Natural Science Foundation of China (Project Numbers: 71901101 and 71973050), the Humanities and Social Sciences Foundation of the Ministry of Education of China (Project Number: 17YJC790044), the Fellowship of China Postdoctoral Science Foundation (Project Number: 2020M671134), and the Fundamental Research Funds for the Central Universities, China (Program Number: 2021JC002).

Institutional Review Board Statement: Not applicable.

Informed Consent Statement: Not applicable. 
Data Availability Statement: The data presented in this study are available on request from the corresponding author.

Acknowledgments: We would like to thank Kaili Peng, Huazhong Agricultural University, for her support of this work.

Conflicts of Interest: The authors declare no conflict of interest.

\section{Notes}

1 The statistical data come from the 2020 Wuhan Statistical Yearbook, 2020 Huangshi City Statistical Yearbook, 2020 Jingmen City Statistical Yearbook, and 2020 Tianmen City Statistical Yearbook. Available online: https:/ / data.cnki.net/NewHome/Index (accessed on 17 October 2021).

\section{References}

1. FAOSTAT. Statistics Division of the Food and Agriculture Organization of the United Nations; FAO: Rome, Italy, 2016.

2. Wauters, E.; Mathijs, E. An Investigation into the Socio-psychological Determinants of Farmers' Conservation Decisions: Method and Implications for Policy, Extension and Research. J. Agric. Educ. Ext. 2013, 19, 53-72. [CrossRef]

3. Liu, X.; Zhang, Y.; Han, W.; Tang, A.; Shen, J.; Cui, Z.; Vitousek, P.; Erisman, J.W.; Goulding, K.; Christie, P.; et al. Enhanced nitrogen deposition over China. Nature 2013, 494, 459-462. [CrossRef]

4. Stuart, D.; Schewe, R.; McDermott, M. Reducing nitrogen fertilizer application as a climate change mitigation strategy: Understanding farmer decision-making and potential barriers to change in the US. Land Use Policy 2014, 36, 210-218. [CrossRef]

5. Zhang, W.-F.; Dou, Z.-X.; He, P.; Ju, X.-T.; Powlson, D.; Chadwick, D.; Norse, D.; Lu, Y.-L.; Zhang, Y.; Wu, L.; et al. New technologies reduce greenhouse gas emissions from nitrogenous fertilizer in China. Proc. Natl. Acad. Sci. USA 2013, 110, 8375-8380. [CrossRef] [PubMed]

6. Smith, L.; Siciliano, G. A comprehensive review of constraints to improved management of fertilizers in China and mitigation of diffuse water pollution from agriculture. Agric. Ecosyst. Environ. 2015, 209, 15-25. [CrossRef]

7. Mózner, Z.; Tabi, A.; Csutora, M. Modifying the yield factor based on more efficient use of fertilizer-The environmental impacts of intensive and extensive agricultural practices. Ecol. Indic. 2012, 16, 58-66. [CrossRef]

8. Carter, C.A.; Zhong, F.; Zhu, J. Advances in Chinese agriculture and its global implications. Appl. Econ. Perspect. Policy 2012, 34, 1-36. [CrossRef]

9. Sun, B.; Zhang, L.; Yang, L.; Zhang, F.; Norse, D.; Zhu, Z. Agricultural non-point source pollution in China: Causes and mitigation measures. Ambio 2012, 41, 370-379. [CrossRef]

10. Li, B.; Shen, Y. Effects of land transfer quality on the application of organic fertilizer by large-scale farmers in China. Land Use Policy 2021, 100, 105124. [CrossRef]

11. Lu, H.; Zhang, P.; Hu, H.; Xie, H.; Yu, Z.; Chen, S. Effect of the grain-growing purpose and farm size on the ability of stable land property rights to encourage farmers to apply organic fertilizers. J. Environ. Manag. 2019, 251, 109621. [CrossRef]

12. Chen, Y.; Jiang, Z.; Wu, D.; Wang, H.; Li, J.; Bi, M.; Zhang, Y. Development of a novel bio-organic fertilizer for the removal of atrazine in soil. J. Environ. Manag. 2019, 233, 553-560. [CrossRef] [PubMed]

13. Xu, Y.; Huang, X.; Bao, H.X.H.; Ju, X.; Zhong, T.; Chen, Z.; Zhou, Y. Rural land rights reform and agro-environmental sustainability: Empirical evidence from China. Land Use Policy 2018, 74, 73-87. [CrossRef]

14. Penha, H.G.V.; Menezes, J.F.S.; Silva, C.A.; Lopes, G.; Carvalho, C.D.A.; Ramos, S.J.; Guilherme, L.R.G. Nutrient accumulation and availability and crop yields following long-term application of pig slurry in a Brazilian Cerrado soil. Nutr. Cycl. Agroecosyst. 2015, 101, 259-269. [CrossRef]

15. Xu, M.-G.; Li, D.-C.; Li, J.-M.; Qin, D.-Z.; Kazuyuki, Y.; Hosen, Y. Effects of organic manure application with chemical fertilizers on nutrient absorption and yield of rice in Hunan of Southern China. Agric. Sci. China 2008, 7, 1245-1252. [CrossRef]

16. Yang, Y.; He, Y.; Li, Z. Social capital and the use of organic fertilizer: An empirical analysis of Hubei Province in China. Environ. Sci. Pollut. Res. 2020, 27, 15211-15222. [CrossRef]

17. Michelini, J.J. Small farmers and social capital in development projects: Lessons from failures in Argentina's rural periphery. J. Rural. Stud. 2013, 30, 99-109. [CrossRef]

18. Li, G.; Rozelle, S.; Brandt, L. Tenure, land rights, and farmer investment incentives in China. Agric. Econ. 1998, 19, 63-71. [CrossRef]

19. Brandt, L.; Rozelle, S.; Turner, M.A. Local government behavior and property right formation in rural China. J. Institutional Theor Econ. (JITE)/Z. für die Gesamte Staatswiss. 2004, 160, 627-662. [CrossRef]

20. Wang, Y.; Zhu, Y.; Zhang, S.; Wang, Y. What could promote farmers to replace chemical fertilizers with organic fertilizers? J. Clean. Prod. 2018, 199, 882-890. [CrossRef]

21. Kousar, R.; Abdulai, A. Off-farm work, land tenancy contracts and investment in soil conservation measures in rural Pakistan. Aust. J. Agric. Resour. Econ. 2015, 60, 307-325. [CrossRef]

22. Pan, D.; Kong, F.; Zhang, N.; Ying, R. Knowledge training and the change of fertilizer use intensity: Evidence from wheat farmers in China. J. Environ. Manag. 2017, 197, 130-139. [CrossRef] 
23. Huang, J.; Huang, Z.; Jia, X.; Hu, R.; Xiang, C. Long-term reduction of nitrogen fertilizer use through knowledge training in rice production in China. Agric. Syst. 2015, 135, 105-111. [CrossRef]

24. Aimin, H. Uncertainty, risk aversion and risk management in agriculture. Agric. Agric. Sci. Procedia 2010, 1, 152-156. [CrossRef]

25. Babcock, B.A. The effects of uncertainty on optimal nitrogen applications. Rev. Agric. Econ. 1992, 14, 271-280. [CrossRef]

26. Chen, X.; Zeng, D.; Xu, Y.; Fan, X. Perceptions, risk attitude and organic fertilizer investment: Evidence from rice and banana farmers in Guangxi, China. Sustainability 2018, 10, 3715. [CrossRef]

27. Xu, H.; Huang, X.; Zhong, T.; Chen, Z.; Yu, J. Chinese land policies and farmers' adoption of organic fertilizer for saline soils. Land Use Policy 2014, 38, 541-549. [CrossRef]

28. Bai, Y.; Kung, J.K.S.; Zhao, Y. How much expropriation hazard is too much? The effect of land reallocation on organic fertilizer usage in rural China. Land Econ. 2014, 90, 434-457. [CrossRef]

29. Hasler, K.; Olfs, H.-W.; Omta, O.; Bröring, S. Drivers for the adoption of eco-innovations in the German fertilizer supply chain. Sustainability 2016, 8, 682. [CrossRef]

30. Schwartz, S.H. Normative influences on altruism. Adv. Exp. Soc. Psychol. 1977, 10, 221-279. [CrossRef]

31. Cordano, M.; Welcomer, S.; Scherer, R.F.; Pradenas, L.; Parada, V. A cross-cultural assessment of three theories of proenvironmental behavior: A comparison between business students of Chile and the United States. Environ. Behav. 2010, 43, 634-657. [CrossRef]

32. Onwezen, M.C.; Antonides, G.; Bartels, J. The Norm Activation Model: An exploration of the functions of anticipated pride and guilt in pro-environmental behaviour. J. Econ. Psychol. 2013, 39, 141-153. [CrossRef]

33. Schultz, P.W.; Zelezny, L.C. Values and proenvironmental behavior: A five-country survey. J. Cross-Cult. Psychol. 1998, $29,540-558$. [CrossRef]

34. De Groot, J.I.M.; Steg, L. Morality and prosocial behavior: The role of awareness, responsibility, and norms in the norm activation model. J. Soc. Psychol. 2009, 149, 425-449. [CrossRef]

35. Han, H.; Hwang, J.; Kim, J.; Jung, H. Guests' pro-environmental decision-making process: Broadening the norm activation framework in a lodging context. Int. J. Hosp. Manag. 2015, 47, 96-107. [CrossRef]

36. Schwartz, S.H.; Howard, J.A. A normative decision making model of altruism. In Altruism and Helping Behavior; Rushton, J.P., Sorrentino, R.M., Eds.; 1981; pp. 89-211. Available online: https:/ / www.scirp.org/(S(lz5mqp453edsnp55rrgjct55))/reference/ ReferencesPapers.aspx?ReferenceID=1031059 (accessed on 17 October 2021).

37. Klöckner, C.A.; Blöbaum, A. A comprehensive action determination model: Toward a broader understanding of ecological behaviour using the example of travel mode choice. J. Environ. Psychol. 2010, 30, 574-586. [CrossRef]

38. Vining, J.; Ebreo, A. Predicting recycling behavior from global and specific environmental attitudes and changes in recycling opportunities1. J. Appl. Soc. Psychol. 1992, 22, 1580-1607. [CrossRef]

39. Zhang, Y.; Wang, Z.; Zhou, G. Antecedents of employee electricity saving behavior in organizations: An empirical study based on norm activation model. Energy Policy 2013, 62, 1120-1127. [CrossRef]

40. Bamberg, S.; Hunecke, M.; Blöbaum, A. Social context, personal norms and the use of public transportation: Two field studies. J. Environ. Psychol. 2007, 27, 190-203. [CrossRef]

41. Kollmuss, A.; Agyeman, J. Mind the Gap: Why do people act environmentally and what are the barriers to pro-environmental behavior? Environ. Educ. Res. 2002, 8, 239-260. [CrossRef]

42. Han, H. The norm activation model and theory-broadening: Individuals' decision-making on environmentally-responsible convention attendance. J. Environ. Psychol. 2014, 40, 462-471. [CrossRef]

43. Steg, L.; De Groot, J. Explaining prosocial intentions: Testing causal relationships in the norm activation model. Br. J. Soc. Psychol. 2010, 49, 725-743. [CrossRef] [PubMed]

44. Hunecke, M.; Matthies, E.; Blöbaum, A.; Matthies, E.; Höger, R.; Blöbaum, A.; Matthies, E.; Höger, R. Responsibility and environment: Ecological norm orientation and external factors in the domain of travel mode choice behavior. Environ. Behav. 2001, 33, 830-852. [CrossRef]

45. Valle, P.O.D.; Rebelo, E.; Reis, E.; Menezes, J. Combining behavioral theories to predict recycling involvement. Environ. Behav. 2005, 37, 364-396. [CrossRef]

46. Wall, R.; Devine-Wright, P.; Mill, G.A. Comparing and combining theories to explain proenvironmental intentions: The case of commuting-mode choice. Environ. Behav. 2007, 39, 731-753. [CrossRef]

47. Hopper, J.R.; Nielsen, J.M. Recycling as altruistic behavior: Normative and behavioral strategies to expand participation in a community recycling program. Environ. Behav. 1991, 23, 195-220. [CrossRef]

48. Wondolleck, J.M.; Yaffee, S.L. Making Collaboration Work: Lessons from Innovation in Natural Resource Managment; Island Press: Washington, DC, USA, 2000; ISBN 1559634626.

49. Blackstock, K.; Ingram, J.; Burton, R.; Brown, K.; Slee, B. Understanding and influencing behaviour change by farmers to improve water quality. Sci. Total Environ. 2010, 408, 5631-5638. [CrossRef]

50. Han, H.; Hsu, L.-T.; Lee, J. Empirical investigation of the roles of attitudes toward green behaviors, overall image, gender, and age in hotel customers' eco-friendly decision-making process. Int. J. Hosp. Manag. 2009, 28, 519-528. [CrossRef]

51. Kim, Y.J.; Njite, D.; Hancer, M. Anticipated emotion in consumers' intentions to select eco-friendly restaurants: Augmenting the theory of planned behavior. Int. J. Hosp. Manag. 2013, 34, 255-262. [CrossRef] 
52. Klöckner, C.A. A comprehensive model of the psychology of environmental behaviour-A meta-analysis. Glob. Environ. Chang. 2013, 23, 1028-1038. [CrossRef]

53. Matthies, E.; Selge, S.; Klöckner, C.A. The role of parental behaviour for the development of behaviour specific environmental norms-The example of recycling and re-use behaviour. J. Environ. Psychol. 2012, 32, 277-284. [CrossRef]

54. Ajzen, I. The theory of planned behavior-organizational behavior and human decision processes 50. Perceived behavioral control, self-efficacy, locus of control, and the theory of planned behavior. Behav. J. Appl. Soc. Psychol. 1991, 32, 665-683. [CrossRef]

55. Bamberg, S.; Möser, G. Twenty years after Hines, Hungerford, and Tomera: A new meta-analysis of psycho-social determinants of pro-environmental behaviour. J. Environ. Psychol. 2007, 27, 14-25. [CrossRef]

56. Klöckner, C.A.; Matthies, E. How habits interfere with norm-directed behaviour: A normative decision-making model for travel mode choice. J. Environ. Psychol. 2004, 24, 319-327. [CrossRef]

57. Ling, M.; Xu, L. Relationships between personal values, micro-contextual factors and residents' pro-environmental behaviors: An explorative study. Resour. Conserv. Recycl. 2020, 156, 104697. [CrossRef]

58. Lal, B.; Sharma, S.; Meena, R.; Sarkar, S.; Sahoo, A.; Balai, R.C.; Gautam, P.; Meena, B. Utilization of byproducts of sheep farming as organic fertilizer for improving soil health and productivity of barley forage. J. Environ. Manag. 2020, 269, 110765. [CrossRef]

59. Ma, W.; Abdulai, A.; Goetz, R. Agricultural cooperatives and investment in organic soil amendments and chemical fertilizer in China. Am. J. Agric. Econ. 2017, 100, 502-520. [CrossRef]

60. Tanner, C.; Kast, S.W. Promoting sustainable consumption: Determinants of green purchases by Swiss consumers. Psychol. Mark. 2003, 20, 883-902. [CrossRef]

61. Cialdini, R.B.; Kallgren, C.A.; Reno, R.R. A Focus theory of normative conduct: A theoretical refinement and reevaluation of the role of norms in human behavior. Adv. Exp. Soc. Psychol. 1991, 24, 201-234. [CrossRef]

62. Hair, J.F., Jr.; Hult, G.T.M.; Ringle, C.; Sarstedt, M. A Primer on Partial Least Squares Structural Equation Modeling (PLS-SEM); Sage Publications: Thousand Oaks, CA, USA, 2016; ISBN 1-4833-7743-1.

63. Holden, S.; Lunduka, R. Do fertilizer subsidies crowd out organic manures? The case of Malawi. Agric. Econ. 2012, 43, 303-314. [CrossRef]

64. Yin, J.; Shi, S. Analysis of the mediating role of social network embeddedness on low-carbon household behaviour: Evidence from China. J. Clean. Prod. 2019, 234, 858-866. [CrossRef]

65. Chen, W.; Li, J. Who are the low-carbon activists? Analysis of the influence mechanism and group characteristics of low-carbon behavior in Tianjin, China. Sci. Total Environ. 2019, 683, 729-736. [CrossRef]

66. Walder, p.; Kantelhardt, j. the environmental behaviour of farmers — capturing the Diversity of Perspectives with a Q methodological Approach. Ecol. Econ. 2018, 143, 55-63. [CrossRef]

67. Gkargkavouzi, A.; Halkos, G.; Matsiori, S. How do motives and knowledge relate to intention to perform environmental behavior? Assessing the mediating role of constraints. Ecol. Econ. 2019, 165, 106394. [CrossRef]

68. Lee, Y.-J.; De Young, R.; Marans, R.W. Factors influencing individual recycling behavior in office settings: A study of office workers in Taiwan. Environ. Behav. 1995, 27, 380-403. [CrossRef]

69. Scherbaum, C.A.; Popovich, P.M.; Finlinson, S. Exploring individual-level factors related to employee energy-conservation behaviors at work 1. J. Appl. Soc. Psychol. 2008, 38, 818-835. [CrossRef]

70. Siero, F.W.; Bakker, A.B.; Dekker, G.B.; Van Den Burg, M.T. Changing organizational energy consumption behaviour through comparative feedback. J. Environ. Psychol. 1996, 16, 235-246. [CrossRef]

71. Harland, P.; Staats, H.; Wilke, H.A.M. Situational and personality factors as direct or personal norm mediated predictors of pro-environmental behavior: Questions derived from norm-activation theory. Basic Appl. Soc. Psychol. 2007, 29, 323-334. [CrossRef]

72. Abrahamse, W.; Steg, L. How do socio-demographic and psychological factors relate to households' direct and indirect energy use and savings? J. Econ. Psychol. 2009, 30, 711-720. [CrossRef]

73. Chan, E.S.; Hon, A.H.; Chan, W.; Okumus, F. What drives employees' intentions to implement green practices in hotels? The role of knowledge, awareness, concern and ecological behaviour. Int. J. Hosp. Manag. 2014, 40, 20-28. [CrossRef]

74. Van Riper, C.J.; Kyle, G.T. Understanding the internal processes of behavioral engagement in a national park: A latent variable path analysis of the value-belief-norm theory. J. Environ. Psychol. 2014, 38, 288-297. [CrossRef] 